\title{
Synthesis, crystal structure and reactivity of $\mathrm{Os}_{3}(\mathrm{CO}){ }_{9}\left(\mu_{3}-\eta^{2}-\mathrm{C}_{2} \mathrm{Ph}_{2}\right)(\mu-\mathrm{C}(\mathrm{OMe}) \mathrm{Ph})$
}

\author{
Wen-Yann Yeh and Shu-Ling Chen \\ Department of Chemistry, National Sun Yat-Sen University, Kaohsiung 80424 (Taiwan)
}

\author{
Shie-Ming Peng ${ }^{1}$ and Gene-Hsiang Lee \\ Department of Chemistry, National Taiwan University, Taipei 10764 (Taiwan)
}

(Received March 12, 1993; in revised form April 17, 1993)

\begin{abstract}
$\mathrm{Os}_{3}(\mathrm{CO})_{9}\left(\mu_{3}-\eta^{2}-\mathrm{C}_{2} \mathrm{Ph}_{2} \mathrm{X} \mu-\mathrm{C}(\mathrm{OMe}) \mathrm{Ph}\right)(1)$ has been prepared by treatment of $\mathrm{Os}_{3}(\mathrm{CO})_{10}\left(\mu_{3}-\eta^{2}-\mathrm{C}_{2} \mathrm{Ph}_{2}\right)$ sequentially with $\mathrm{PhLi}$ and $\mathrm{MeOSO}_{2} \mathrm{CF}_{3}$. Protonation of 1 with $\mathrm{HBF}_{4}$ gives $\left\{\left[\mathrm{Os}_{3}(\mathrm{CO})_{9}\left(\mu-\eta^{3}-\mathrm{C}_{3} \mathrm{Ph}_{3}\right)^{+}\right]\left[\mathrm{BF}_{4}^{-}\right]\right\}(2)$, which leads to the well-known $(\mu-\mathrm{H}) \mathrm{Os}_{3}(\mathrm{CO})_{9}\left(\mu_{3}-\eta^{3}-\mathrm{C}_{3} \mathrm{Ph}_{3}\right)(3)$ and $\mathrm{Os}_{3}(\mathrm{CO})_{9}\left(\mu_{3}-\eta^{2}-\mathrm{C}_{2} \mathrm{Ph}_{2}\right)(\mu-\mathrm{CHPh})(4)$ upon hydride attack. Thermolysis of 1 in refluxing hexane produces mainly $\mathrm{Os}_{3}(\mathrm{CO})_{9}\left(\mu_{3}-\eta^{2}-\mathrm{C}_{2} \mathrm{Ph}_{2}\right)\left(\mu-\mathrm{CH}_{2}\right)(5)$. Compound 1 crystallizes in the space group $P \overline{1}$ with $a=10.032(1)$ $\AA, b=10.119(2) \AA, c=16.972(2) \AA, \alpha=97.06(2)^{\circ}, \beta=94.65(1)^{\circ}, \gamma=98.80(2)^{\circ}, V=1681.0(5) \AA^{3}, Z=2$ and $R_{F}=3.2 \%$.
\end{abstract}

\section{Introduction}

The transition metal complexes containing $\mu$ alkylidene ligands have been a subject of increasingly intense study [1]. In particular, the reactivity of $\mu$-alkylidenes toward unsaturated hydrocarbons has attracted much attention because it might provide mechanistic information of surface-bound $\mathrm{C}_{1}$ and $\mathrm{C}_{2}$ units in some catalytic reactions, such as metal-promoted $\mathrm{CH}_{2}$ transformation, reduction of $\mathrm{CO}$ to alkanes, olefin metathesis and alkyne polymerization [2]. The $\mu$-alkylidene compounds are commonly prepared from interaction of $\mathrm{CH}_{2} \mathrm{~N}_{2}$ or other diazoalkanes with complexes having metal-metal bonds [3], reaction of metal carbene complexes with other metal complexes that have weakly bound ligands [4], or nucleophilic attack at bridging alkylidyne carbon atoms [5]. In this paper we report the synthesis and crystal structure of $\mathrm{Os}_{3}(\mathrm{CO})_{9}$ $\left(\mu_{3}-\eta^{2}-\mathrm{C}_{2} \mathrm{Ph}_{2}\right)(\mu-\mathrm{C}(\mathrm{OMe}) \mathrm{Ph})$, which contains a bridging phenylmethoxycarbene ligand arising from a coordinated carbonyl, as well as its reactivity leading to alkylidyne-alkyne coupling [6].

\footnotetext{
Correspondence to: Dr. W.-Y. Yeh.

${ }^{1}$ Author to whom queries concerning the $\mathrm{X}$-ray crystallographic work should be addressed.
}

\section{Experimental section}

\subsection{General procedures}

$\mathrm{Os}_{3}(\mathrm{CO})_{10}\left(\mu_{3}-\eta^{2}-\mathrm{C}_{2} \mathrm{Ph}_{2}\right)$ was prepared from $\mathrm{Os}_{3}-$ $(\mathrm{CO})_{10}(\mathrm{NCMe})_{2}$ and diphenylacetylene as described in the literature [7]. ${ }^{13} \mathrm{CO}$-enriched $\mathrm{Os}_{3}(\mathrm{CO})_{12}$ (about $33 \%$ enriched) was prepared by heating a solution of $\mathrm{Os}_{3}(\mathrm{CO})_{12}$ in dry decalin at $110^{\circ} \mathrm{C}$ for $48 \mathrm{~h}$ under 6 equivalents of ${ }^{13} \mathrm{CO}(99 \%$; Isotec) in a pressure bottle. Phenyl lithium (Janssen; $2 \mathrm{M}$ in cyclohexane-ether), methyl trifluoromethanesulphonate (Aldrich), tetrafluoroboric acid (Merck; $54 \%$ in $\mathrm{Et}_{2} \mathrm{O}$ ) and lithium triethylborohydride (Aldrich; $1.0 \mathrm{M}$ in tetrahydrofuran) were used directly as received. Diethyl ether was distilled from sodium benzophenone ketyl, and hexane was distilled from sodium immediately before use. Preparative thin-layer chromatographic (TLC) plates were prepared from silica gel (Merck, GF254). ${ }^{1} \mathrm{H}$ and ${ }^{13} \mathrm{C}$ nuclear magnetic resonance (NMR) spectra were obtained on a Varian VXR-300 spectrometer at $300 \mathrm{MHz}$ and $75.4 \mathrm{MHz}$ respectively. IR spectra were taken on a Hitachi-2001 spectrometer. Mass spectra were obtained on a JEOL-HX 110 mass spectrometer. Elemental analyses were performed at the National Science Council Regional Instrumentation Center, National Chen-Kung University, Tainan. 


\subsection{Preparation of $\mathrm{Os}_{3}(\mathrm{CO})_{9}\left(\mu_{3}-\eta^{2}-\mathrm{C}_{2} P h_{2}\right)(\mu-\mathrm{C}$ -} (OMe)Ph) from $\mathrm{Os}_{3}(\mathrm{CO})_{10}\left(\mu_{3}-\eta^{2}-C_{2} \mathrm{Ph}_{2}\right)$

An oven-dried $100 \mathrm{ml}$ Schlenk flask was equipped with a magnetic stir bar and a rubber serum stopper. A solution of $\mathrm{Os}_{3}(\mathrm{CO})_{10}\left(\mu_{3}-\eta^{2}-\mathrm{C}_{2} \mathrm{Ph}_{2}\right)(150 \mathrm{mg}, 0.146$ $\mathrm{mmol})$ in diethyl ether $(10 \mathrm{ml})$ was introduced under nitrogen by means of a cannula through the serum stopper. After the mixture had been cooled to $0^{\circ} \mathrm{C}$ with an ice bath, phenyl lithium (180 $\mu 1,0.36 \mathrm{mmol})$ was added via a syringe over a period of $30 \mathrm{~min}$ and methyl trifluoromethanesulphonate $(70 \mu 1,0.62 \mathrm{mmol})$ then added via a syringe. The solution was concentrated to about $2 \mathrm{ml}$ under vacuum, placed under nitrogen and then stirred for $30 \mathrm{~min}$ at room temperature. The volatile materials were removed under vacuum, and the residue was purified by TLC, eluting with $\mathrm{n}$ hexane-dichloromethane $(4: 1, v / v)$. Crystallization of the orange band from methanol-dichloromethane yielded air-stable crystals formulated as $\mathrm{Os}_{3}(\mathrm{CO})_{9}\left(\mu_{3^{-}}\right.$$\left.\eta^{2}-\mathrm{C}_{2} \mathrm{Ph}_{2}\right)(\mu$-C(OMe)Ph) (1) (112 mg, $0.1 \mathrm{mmol} ; 69 \%$; melting point, $112-114^{\circ} \mathrm{C}$ dec.). Mass spectroscopy (FAB) $m / z$ : $1126\left(\mathrm{M}^{+},{ }^{192} \mathrm{Os}\right), 1126-28 n(n=1-9)$. IR $\left(\mathrm{C}_{6} \mathrm{H}_{12}\right): \nu(\mathrm{CO}) 2091 \mathrm{~s}, 2063 \mathrm{vs}, 2056 \mathrm{~s}, 2051 \mathrm{~s}, 2025 \mathrm{~s}$, $2019 \mathrm{~m}, 2009 \mathrm{~m}, 2001 \mathrm{~m}, 1990 \mathrm{~m} \mathrm{~cm}^{-1} .{ }^{1} \mathrm{H}$ NMR $\left(\mathrm{CD}_{2} \mathrm{Cl}_{2}\right.$, $\left.25^{\circ} \mathrm{C}\right): 7.66-6.64(\mathrm{~m}, 15 \mathrm{H}, \mathrm{Ph}), 3.60\left(\mathrm{~s}, 3 \mathrm{H}, \mathrm{OCH}_{3}\right)$ ppm. ${ }^{13} \mathrm{C}\left({ }^{1} \mathrm{H}\right) \mathrm{NMR}\left(\mathrm{CDCl}_{3}, 25^{\circ} \mathrm{C}\right): 211.1$ (C(OMe)Ph), $185.7(2 \mathrm{CO}), 178.5(1 \mathrm{CO}), 176.0(\mathrm{C} \equiv \mathrm{C}), 174.1(2 \mathrm{CO})$, 173.4 (2CO), 172.3 (2CO), 156.5, 150.8, 129.4, 128.0, $127.8,127.7,127.5,127.1\left(\mathrm{C}_{6} \mathrm{H}_{5}\right), 61.5\left(\mathrm{OCH}_{3}\right) \mathrm{ppm}$. Anal. Found: $\mathrm{C}, 33.26 ; \mathrm{H}, 1.62 . \mathrm{Os}_{3} \mathrm{C}_{31} \mathrm{H}_{18} \mathrm{O}_{10}$ calc.: $\mathrm{C}$, $33.21 ; \mathrm{H}, 1.62 \%$.

The crystal of compound 1 found suitable for X-ray analysis was grown from methanol-dichloromethane at $-20^{\circ} \mathrm{C}$.

2.3. Reaction of $\mathrm{Os}_{3}(\mathrm{CO})_{9}\left(\mu_{3}-\eta^{2}-\mathrm{C}_{2} \mathrm{Ph}_{2}\right)(\mu-\mathrm{C}(\mathrm{OMe}) \mathrm{Ph})$ with tetrafluoroboric acid to form $\left\{\mathrm{lOs}_{3}(\mathrm{CO})_{9}\left(\mu-\eta^{3}\right.\right.$ $\left.\mathrm{C}_{3} \mathrm{Ph}_{3}\right)+\left[\left[\mathrm{BF}_{4}^{-}\right]\right\}$

$\mathrm{Os}_{3}(\mathrm{CO})_{9}\left(\mu_{3}-\eta^{2}-\mathrm{C}_{2} \mathrm{Ph}_{2}\right)(\mu-\mathrm{C}(\mathrm{OMe}) \mathrm{Ph})(1)(20 \mathrm{mg}$, $0.02 \mathrm{mmol})$ and diethyl ether $(3 \mathrm{ml})$ were added to an oven-dried $25 \mathrm{ml}$ Schlenk flask under an atmosphere of nitrogen. Tetrafluoroboric acid ( $5 \mu \mathrm{l}, 0.03 \mathrm{mmol})$ was added via a syringe. The solution was placed under nitrogen and stirred at ambient temperature for $1 \mathrm{~h}$, forming a yellow slurry. The mixture was then cooled to $0^{\circ} \mathrm{C}$ with an ice bath to facilitate precipitation of the pale-yellow solid. The supernatant was removed by pipette, and the precipitate was washed with cold diethyl ether $(3 \times 3 \mathrm{ml})$ and dried under vacuum for $16 \mathrm{~h}$. The slightly air-sensitive pale-yellow solid was formulated as $\left\{\left[\mathrm{Os}_{3}(\mathrm{CO})_{9}\left(\mu-\eta^{3}-\mathrm{C}_{3} \mathrm{Ph}_{3}\right)^{+}\right]\left[\mathrm{BF}_{4}^{-}\right]\right\}$(2) $(19 \mathrm{mg}$, $0.016 \mathrm{mmol} ; 80 \%$ ) on the basis of spectroscopic data. IR $\left(\mathrm{CH}_{2} \mathrm{Cl}_{2}\right): \nu(\mathrm{CO}) 2122 \mathrm{~m}, 2092 \mathrm{~s}, 2086 \mathrm{~s}, 2056 \mathrm{~m}$, $2036 \mathrm{~m} \mathrm{~cm}^{-1}$. ${ }^{1} \mathrm{H}$ NMR (acetone- $d_{6}, 25^{\circ} \mathrm{C}$ ): $7.63-7.24$ (m, Ph) ppm. ${ }^{13} \mathrm{C}\left({ }^{1} \mathrm{H}\right)$ NMR (acetone- $d_{6}, 25^{\circ} \mathrm{C}$ ): 184.8 (s, 1CO), 177.8 (s, 2CO), 176.6 (s, br, CPh), 175.8 (s, $1 \mathrm{CO}), 175.4$ (s, 4CO), 171.7 (s, 1CO), 158.2-125.5 (m, $\mathrm{C}_{6} \mathrm{H}_{5}$ ) ppm. Anal. Found: C, 31.02; H, 1.40 . $\mathrm{Os}_{3} \mathrm{C}_{30} \mathrm{H}_{15} \mathrm{O}_{9} \mathrm{BF}_{4}$ calc.: $\mathrm{C}, 30.63 ; \mathrm{H}, 1.29 \%$.

\subsection{Reaction of $\left\{\left[\mathrm{OOs}_{3}(\mathrm{CO})_{9}\left(\mu-\eta^{3}-\mathrm{C}_{3} \mathrm{Ph}_{3}\right)+\right]\left[\mathrm{BF}_{4}^{-}\right]\right\}$ with lithium triethylborohydride}

$\left\{\left[\mathrm{Os}_{3}(\mathrm{CO})_{9}\left(\mu-\eta^{3}-\mathrm{C}_{3} \mathrm{Ph}_{3}\right)^{+}\right]\left[\mathrm{BF}_{4}^{-}\right]\right\}$(2) (21 mg, 0.02 mmol) was placed in an oven-dried $50 \mathrm{ml}$ Schlenk flask equipped with a magnetic stir bar and a rubber serum stopper under an atmosphere of nitrogen in a glove box. Diethyl ether $(3 \mathrm{ml})$ was introduced by a cannula through the serum stopper. The mixture was cooled to $0^{\circ} \mathrm{C}$ with an ice bath, and lithium triethylborohydride ( $20 \mu 1,0.02 \mathrm{mmol}$ ) was added via a syringe. The slurry was vigorously stirred under nitrogen for $50 \mathrm{~min}$ at $0^{\circ} \mathrm{C}$, at which point the solution became clear. The volatile materials were removed under vacuum and the residue applied on TLC, eluting with n-hexane. Isolation of the materials forming the first, orange band and the second, yellow band gave the known $\mathrm{Os}_{3}(\mathrm{CO})_{9}\left(\mu_{3}-\eta^{2}\right.$ $\left.\mathrm{C}_{2} \mathrm{Ph}_{2}\right)(\mu-\mathrm{CHPh})(4)$ [8] (4 mg, $\left.0.004 \mathrm{mmol} ; 21 \%\right)$ and $(\mu-\mathrm{H}) \mathrm{Os}_{3}(\mathrm{CO})_{9}\left(\mu_{3}-\eta^{3}-\mathrm{C}_{3} \mathrm{Ph}_{3}\right)$ (3) [9] (9 mg, 0.008 mmol; 46\%) respectively.

\subsection{Thermolysis of $\mathrm{Os}_{3}(\mathrm{CO})_{9}\left(\mu_{3}-\eta^{2}-\mathrm{C}_{2} P h_{2}\right)(\mu-C-$ $(\mathrm{OMe}) \mathrm{Ph})$}

An oven-dried $250 \mathrm{ml}$ three-necked round-bottomed flask was equipped with a magnetic stir bar, a rubber serum stopper, a reflux condenser, and a nitrogen inlet. The stopper was briefly removed, and $\mathrm{Os}_{3}(\mathrm{CO})_{9}\left(\mu_{3}-\eta^{2}-\mathrm{C}_{2} \mathrm{Ph}_{2}\right)(\mu-\mathrm{C}(\mathrm{OMe}) \mathrm{Ph})$ (1) $(100 \mathrm{mg}$, $0.089 \mathrm{mmol})$ and $\mathrm{n}$-hexane $(130 \mathrm{ml})$ were added against a nitrogen flow. The solution was refluxed under nitrogen for $6 \mathrm{~h}$. After cooling to room temperature, the solvent was removed under vacuum, and the residue subjected to TLC, eluting with $\mathrm{n}$-hexane. The known $\mathrm{Os}_{3}(\mathrm{CO})_{9}\left(\mu_{3}-\eta^{2}-\mathrm{C}_{2} \mathrm{Ph}_{2}\right)\left(\mu-\mathrm{CH}_{2}\right)(5)$ [10] (39 mg, 0.038 $\mathrm{mmol} ; 43 \%)$ was isolated as the major product.

\subsection{Collection of $X$-ray diffraction data and structure solution for $\mathrm{Os}_{3}(\mathrm{CO})_{9}\left(\mu_{3}-\eta^{2}-\mathrm{C}_{2} \mathrm{Ph}_{2}\right)(\mu-\mathrm{C}(\mathrm{OMe}) \mathrm{Ph})$}

An orange crystal of $\mathrm{Os}_{3}(\mathrm{CO})_{9}\left(\mu_{3}-\eta^{2}-\mathrm{C}_{2} \mathrm{Ph}_{2}\right)(\mu$ $\mathrm{C}(\mathrm{OMe}) \mathrm{Ph})(1)$ with approximate dimensions $0.25 \mathrm{~mm}$ $\times 0.35 \mathrm{~mm} \times 0.55 \mathrm{~mm}$ was mounted in a thin-walled glass capillary and aligned on the Nonius CAD-4 diffractometer. Lattice parameters were determined from 25 randomly selected reflections with $2 \theta$ angle in the range $19.00-25.22^{\circ}$. All data were corrected for Lorentz and polarization effects and for the effects of absorption. The structure was solved by the heavy-atom method and refined by least-square cycles; all non-hydrogen atoms were refined with anisotropic thermal 
TABLE 1. Experimental data for the X-ray diffraction study for compound 1

\begin{tabular}{|c|c|}
\hline $\begin{array}{l}\text { Formula } \\
\text { Crystal solvent } \\
\text { Crystal system }\end{array}$ & $\begin{array}{l}\mathrm{C}_{31} \mathrm{H}_{18} \mathrm{O}_{10} \mathrm{Os}_{3} \\
\mathrm{CH}_{2} \mathrm{Cl}_{2} \\
\text { Triclinic }\end{array}$ \\
\hline Space group & $P \overline{1}$ \\
\hline$a(\AA)$ & $10.032(1)$ \\
\hline$b(\AA)$ & $10.119(2)$ \\
\hline$c(\AA)$ & $16.972(2)$ \\
\hline$\alpha\left({ }^{\circ}\right)$ & $97.06(2)$ \\
\hline$\beta\left(^{\circ}\right)$ & $94.65(1)$ \\
\hline$\gamma\left({ }^{\circ}\right)$ & $98.80(2)$ \\
\hline$V\left(\AA^{3}\right)$ & $1681.0(5)$ \\
\hline$Z$ & 2 \\
\hline$D_{\text {calc }}\left(\mathrm{g} \mathrm{cm}^{-3}\right)$ & 2.383 \\
\hline$F(000)$ & 1107.64 \\
\hline Diffractomer & Nonius (CAD-4) \\
\hline Radiation; $\lambda(\AA)$ & Mo $\mathrm{K} \alpha ; 0.70930$ \\
\hline Temperature (K) & 298 \\
\hline Crystal size $(\mathrm{mm} \times \mathrm{mm} \times \mathrm{mm})$ & $0.25 \times 0.35 \times 0.55$ \\
\hline Scan method & $\theta-2 \theta$ scan mode \\
\hline $2 \theta_{\max }\left({ }^{\circ}\right)$ & 44.8 \\
\hline Scan parameters & $0.90+0.35 \tan \theta$ \\
\hline Scan speed $\left({ }^{\circ} \min ^{-1}\right)$ & $16.48 / 8$ to $16.48 / 2$ \\
\hline$h, k, l$ range & -10 to 10,0 to $10,-18$ to 18 \\
\hline $\begin{array}{l}\text { Absorption correction method } \\
\mu\left(\mathrm{mm}^{-1}\right)\end{array}$ & $\begin{array}{l}\psi \text { scan } \\
11.54\end{array}$ \\
\hline $\begin{array}{l}\text { Transmission factors: maximum; } \\
\text { minimum }\end{array}$ & $0.999837 ; 0.575296$ \\
\hline Standard reflections (number, 3 ) & Decay, $5 \%$; every $3600 \mathrm{~s}$ \\
\hline Number of unique data & 4373 \\
\hline Number of data with $I>2 \sigma(I)$ & 3744 \\
\hline $\begin{array}{l}\text { Number of atoms and parameters } \\
\text { refined }\end{array}$ & 67,425 \\
\hline Maximum $\Delta / \sigma$ ratio & 0.054 \\
\hline$R_{F} ; R_{w}$ & $0.032 ; 0.025$ \\
\hline GoF & 2.55 \\
\hline $\begin{array}{l}\text { Max/minimum residual electron } \\
\text { density (electrons } \AA^{-3} \text { ) }\end{array}$ & $1.320 /-1.130$ \\
\hline
\end{tabular}

parameters. The data collection and refinement parameters are given in Table 1 . Atomic positional parameters are collected in Table 2 .

\section{Results and discussion}

3.1. Synthesis and spectroscopic characterization of $\mathrm{Os}_{3}(\mathrm{CO})_{9}\left(\mu_{3}-\eta^{2}-\mathrm{C}_{2} \mathrm{Ph}_{2}\right)(\mu-\mathrm{C}(\mathrm{OMe}) \mathrm{Ph})$

A sequential $\mathrm{Ph}^{-}-\mathrm{Me}^{+}$treatment of $\mathrm{Os}_{3}(\mathrm{CO})_{10}\left(\mu_{3^{-}}\right.$ $\left.\eta^{2}-\mathrm{C}_{2} \mathrm{Ph}_{2}\right)$ results in the transformation of $\mathrm{CO} \rightarrow \mathrm{C}$ (OMe)Ph to give $\mathrm{Os}_{3}(\mathrm{CO})_{9}\left(\mu_{3}-\eta^{2}-\mathrm{C}_{2} \mathrm{Ph}_{2}\right)(\mu-\mathrm{C}-$ $(\mathrm{OMe}) \mathrm{Ph})(1)$ with a $69 \%$ yield. It is likely that $\mathrm{Ph}^{-}$ attacks one of the carbonyl ligands to give $\left[\mathrm{Os}_{3}(\mathrm{CO})_{9}\right.$ $\left.\left(\mu_{3}-\eta^{2}-\mathrm{C}_{2} \mathrm{Ph}_{2}\right)(\mu-\mathrm{C}(\mathrm{O}) \mathrm{Ph})^{-}\right]$, and then methylation occurs at the benzoyl oxygen to generate the observed product:

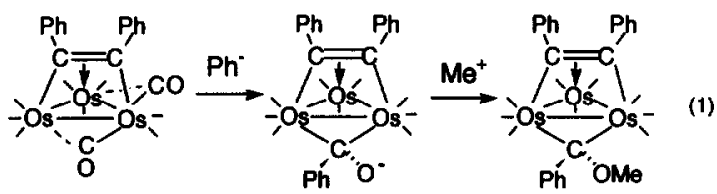

1

TABLE 2. Atomic positional parameters for compound 1

\begin{tabular}{|c|c|c|c|c|}
\hline & $x$ & $y$ & $z$ & $B_{\text {iso }}\left(\AA^{2}\right)$ \\
\hline Os(1) & $0.16355(5)$ & $0.27512(5)$ & $0.11329(3)$ & $2.151(21)$ \\
\hline $\operatorname{Os}(2)$ & $0.34076(5)$ & $0.18259(5)$ & $0.21898(3)$ & $2.245(21)$ \\
\hline $\operatorname{Os}(3)$ & $0.06559(5)$ & $0.11836(4)$ & $0.22379(3)$ & $2.261(20)$ \\
\hline $\mathrm{C}(1)$ & $-0.0228(10)$ & $0.2166(11)$ & $0.0737(6)$ & $2.9(5)$ \\
\hline$C(2)$ & $0.1605(11)$ & $0.4434(11)$ & $0.0788(7)$ & $3.8(6)$ \\
\hline $\mathrm{C}(3)$ & $0.2104(10)$ & $0.1735(11)$ & $0.0154(7)$ & $3.0(6)$ \\
\hline$C(4)$ & $0.5194(10)$ & $0.2655(11)$ & $0.2655(7)$ & $2.9(6)$ \\
\hline$C(5)$ & $0.3956(11)$ & $0.0580(11)$ & $0.1369(7)$ & $3.5(6)$ \\
\hline$C(6)$ & $0.3334(12)$ & $0.0485(11)$ & $0.2841(8)$ & $4.0(7)$ \\
\hline$C(7)$ & $0.0580(12)$ & $-0.0551(12)$ & $0.1648(7)$ & $3.7(6)$ \\
\hline$C(8)$ & $0.0482(11)$ & $0.0512(10)$ & $0.3191(7)$ & $3.4(6)$ \\
\hline $\mathrm{C}(9)$ & $-0.1251(11)$ & $0.1123(13)$ & $0.2128(7)$ & $3.9(7)$ \\
\hline$C(10)$ & $0.3827(10)$ & $0.3446(11)$ & $0.1420(6)$ & $2.5(5)$ \\
\hline$C(11)$ & $0.4363(10)$ & $0.4880(10)$ & $0.1718(6)$ & $2.5(5)$ \\
\hline$C(12)$ & $0.4780(12)$ & $0.5752(11)$ & $0.1187(7)$ & $3.4(6)$ \\
\hline$C(13)$ & $0.5259(12)$ & $0.7107(12)$ & $0.1411(8)$ & $4.3(7)$ \\
\hline$C(14)$ & $0.5371(13)$ & $0.7631(12)$ & $0.2203(8)$ & $4.5(7)$ \\
\hline$C(15)$ & $0.4945(12)$ & $0.6786(12)$ & $0.2747(7)$ & $4.2(7)$ \\
\hline$C(16)$ & $0.4449(11)$ & $0.5435(11)$ & $0.2517(7)$ & $2.9(6)$ \\
\hline$C(17)$ & $0.5910(11)$ & $0.3090(13)$ & $0.0841(8)$ & $4.3(7)$ \\
\hline $\mathrm{C}(18)$ & $0.1282(10)$ & $0.3469(10)$ & $0.2304(6)$ & $2.0(5)$ \\
\hline$C(19)$ & $0.2206(10)$ & $0.3011(10)$ & $0.2844(6)$ & $2.4(5)$ \\
\hline$C(20)$ & $0.0498(10)$ & $0.4574(10)$ & $0.2502(6)$ & $2.2(5)$ \\
\hline$C(21)$ & $0.1149(11)$ & $0.5773(11)$ & $0.2966(7)$ & $3.4(6)$ \\
\hline $\mathrm{C}(22)$ & $0.0478(12)$ & $0.6850(11)$ & $0.3102(7)$ & $3.8(7)$ \\
\hline$C(23)$ & $-0.0819(12)$ & $0.6824(11)$ & $0.2790(7)$ & $3.7(6)$ \\
\hline$C(24)$ & $-0.1451(11)$ & $0.5650(12)$ & $0.2335(7)$ & $4.1(7)$ \\
\hline$C(25)$ & $-0.0808(11)$ & $0.4562(11)$ & $0.2194(7)$ & $3.2(6)$ \\
\hline$C(26)$ & $0.2246(11)$ & $0.3332(10)$ & $0.3756(6)$ & $2.8(6)$ \\
\hline$C(27)$ & $0.3459(12)$ & $0.3458(12)$ & $0.4231(7)$ & $4.0(7)$ \\
\hline$C(28)$ & $0.3525(13)$ & $0.3762(14)$ & $0.5049(7)$ & $5.2(8)$ \\
\hline$C(29)$ & $0.2403(14)$ & $0.3918(14)$ & $0.5417(7)$ & $5.6(8)$ \\
\hline$C(30)$ & $0.1182(13)$ & $0.3796(12)$ & $0.4971(7)$ & $4.5(7)$ \\
\hline$C(31)$ & $0.1088(11)$ & $0.3493(11)$ & $0.4141(7)$ & $3.4(6)$ \\
\hline$O(1)$ & $-0.1306(8)$ & $0.1888(9)$ & $0.0425(5)$ & $4.8(5)$ \\
\hline$O(2)$ & $0.1537(9)$ & $0.5475(9)$ & $0.0579(6)$ & $6.5(6)$ \\
\hline$O(3)$ & $0.2301(8)$ & $0.1133(8)$ & $-0.0422(5)$ & $4.8(5)$ \\
\hline$O(4)$ & $0.6226(8)$ & $0.3116(9)$ & $0.2954(5)$ & $5.0(5)$ \\
\hline$O(5)$ & $0.4219(9)$ & $-0.0164(8)$ & $0.0867(5)$ & $5.7(5)$ \\
\hline$O(6)$ & $0.3373(8)$ & $-0.0321(8)$ & $0.3290(5)$ & $5.3(5)$ \\
\hline$O(7)$ & $0.0551(9)$ & $-0.1581(8)$ & $0.1274(5)$ & $5.3(5)$ \\
\hline$O(8)$ & $0.0448(8)$ & $0.0140(8)$ & $0.3821(5)$ & $4.5(5)$ \\
\hline$O(9)$ & $-0.2413(8)$ & $0.1030(8)$ & $0.2052(5)$ & $4.7(5)$ \\
\hline$O(10)$ & $0.4471(7)$ & $0.3011(7)$ & $0.0745(4)$ & $2.9(4)$ \\
\hline$C(32)$ & $0.742(3)$ & $0.092(3)$ & $0.4772(12)$ & $22.1(27)$ \\
\hline$C(11)$ & $0.6936(7)$ & $0.2386(7)$ & $0.4971(4)$ & $15.7(5)$ \\
\hline$C(12)$ & $0.6943(7)$ & $-0.0058(7)$ & $0.3980(4)$ & 17.1(5) \\
\hline
\end{tabular}




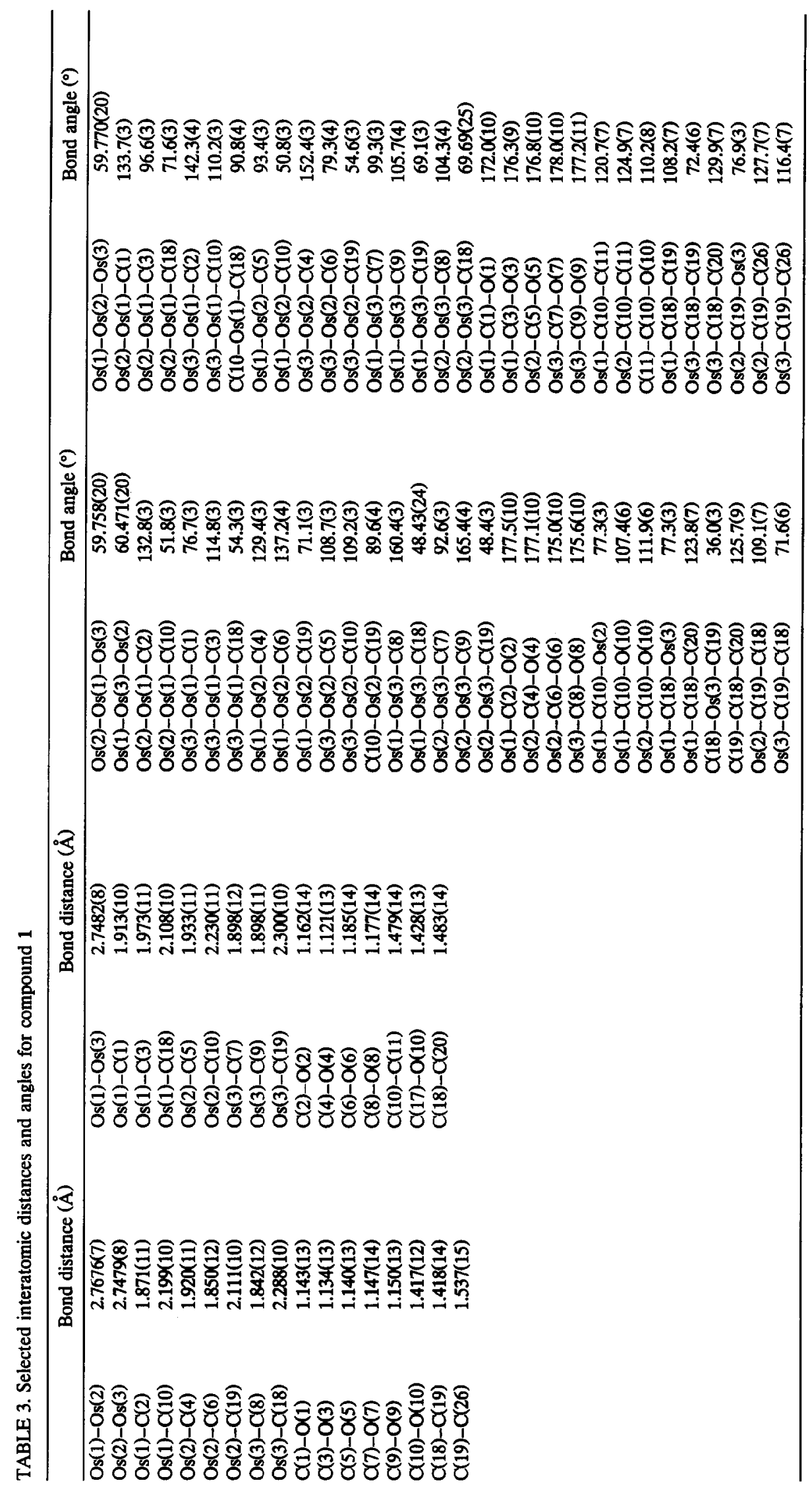


For comparison, Shapley and coworkers [11] have previously shown that sequential $\mathrm{Ph}^{-}-\mathrm{Me}^{+}$treatment is effective for transformation of carbonyl ligands to alkylidene and alkylidyne moieties in related triosmium systems.

The FAB mass spectrum of compound 1 gives the molecular ion peak at $m / z=1126\left({ }^{192} \mathrm{Os}\right)$ and ion multiplets corresponding to loss of nine carbonyls. The IR spectrum in the carbonyl region of compound 1 is compatible with those recorded for $\mathrm{Os}_{3}(\mathrm{CO})_{9}\left(\mu_{3}-\eta^{2}-\right.$ $\left.\mathrm{C}_{2} \mathrm{Ph}_{2}\right)\left(\mu\right.$-CHR), where $\mathrm{R}=\mathrm{H}$ or $\mathrm{Ph}[10,11]$. The ${ }^{1} \mathrm{H}$ NMR spectrum shows a sharp singlet at $3.60 \mathrm{ppm}$, assigned to the methoxy protons, and a complicated multiplet in the range 7.66-6.64 ppm for the phenyl protons. The ${ }^{13} \mathrm{C}$ NMR spectrum for $\mathrm{Os}_{3}\left({ }^{*} \mathrm{CO}\right)_{9}\left(\mu_{3^{-}}\right.$ $\left.\eta^{2}-\mathrm{C}_{2} \mathrm{Ph}_{2}\right)\left(\mu-{ }^{*} \mathrm{C}(\mathrm{OMe}) \mathrm{Ph}\right)($ each enriched site about $33 \%{ }^{13} \mathrm{C}$ ) displays a low field resonance at $211.1 \mathrm{ppm}$, characteristic of bridging alkylidene carbons [12], and the carbonyl carbons in a $2: 1: 2: 2: 2$ pattern in the usual range 185.7-172.3 ppm, implying a time-averaged $C_{\mathrm{s}}$ symmetry for the entire molecule.

\subsection{Crystal structure of $\mathrm{Os}_{3}(\mathrm{CO})_{9}\left(\mu_{3}-\eta^{2}-\mathrm{C}_{2} P h_{2}\right)(\mu-$ $\mathrm{C}(\mathrm{OMe}) \mathrm{Ph})$}

A crystal of compound 1 contains an ordered array of discrete monomeric molecular units which are mutually separated by the normal van der Waals distances. The molecular geometry and atomic labelling scheme are illustrated in Fig. 1. The interatomic distances and angles are collected in Table 3.

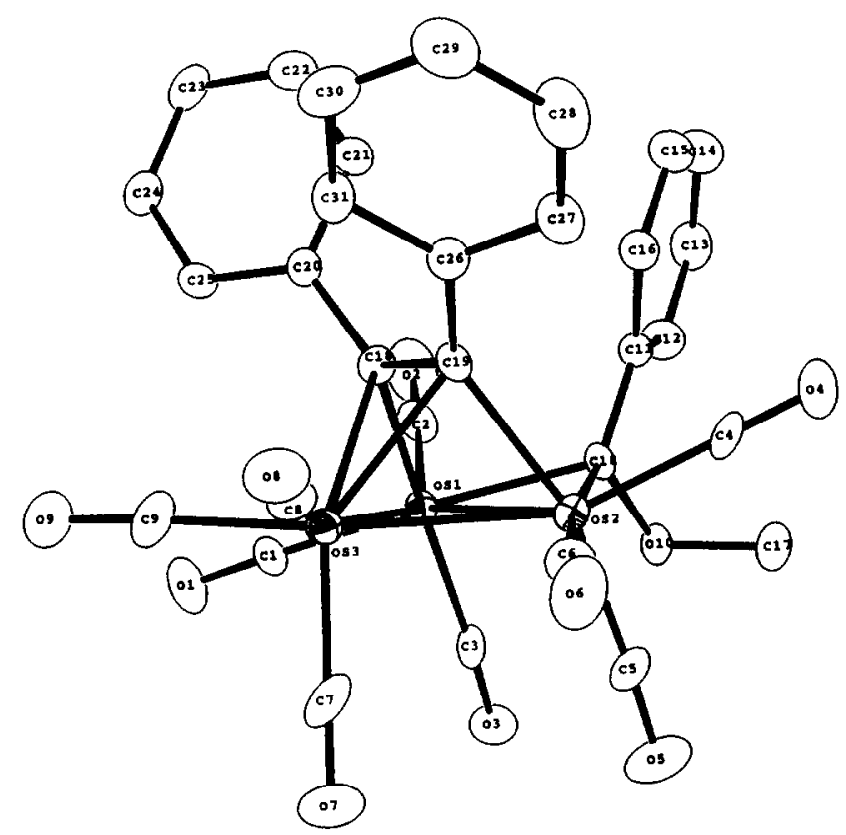

Fig. 1. Molecular structure of $\mathrm{Os}_{3}(\mathrm{CO})_{9}\left(\mu_{3}-\eta^{2}-\mathrm{C}_{2} \mathrm{Ph}_{2}\right)(\mu-\mathrm{C}(\mathrm{OMe})$ $\mathrm{Ph})(1)$, showing the atomic labelling scheme used in the text.
The molecule is based upon a triangular array of osmium atoms in which the dibridged Os(1)-Os(2) distance of $2.7676(7) \AA$ is slightly but significantly longer than the other two intermetallic distances (i.e. an Os(1)-Os(3) distance of $2.7482(8) \AA$ and an Os(2)Os(3) distance of $2.7479(8) \AA)$. A similar difference was found in $\mathrm{Os}_{3}(\mathrm{CO})_{9}\left(\mu_{3}-\eta^{2}-\mathrm{C}_{2} \mathrm{Ph}_{2}\right)\left(\mu-\mathrm{CH}_{2}\right)$, where the dibridged Os-Os distance is about $0.03 \AA$ longer than the other two Os-Os distances [10].

The diphenylacetylene ligand is coordinated to all three osmium atoms, forming a $\pi$ bond to Os(3), with an Os(3)-C(18) distance of 2.29(1) $\AA$ and an Os(3)$\mathrm{C}(19)$ distance of $2.30(1) \AA$, and $\sigma$ bonds to Os(1) and Os(2), with both Os(1)-C(18) and Os(2)-C(19) distances of 2.11(1) $\AA$. The dihedral angle between the triosmium plane and the Os(1)-Os(2)-C(18)-C(19) plane is $59.1(2)^{\circ}$. The Os(1)-Os(2) edge is also bridged by the phenylmethoxycarbene ligand, which is tilted $15.0(4)^{\circ}$ out of the triosmium plane towards the diphenylacetylene, where the Os(1)-C(10) distance, which equals $2.20(1) \AA$, is slightly shorter than the Os(2)-C(10) distance of 2.23(1) $\AA$. Although the molecule has no crystallographically imposed symmetry in the solid state, it exhibits the expected idealized $C_{s}$ symmetry in solution, as evidenced by the ${ }^{13} \mathrm{C}$ NMR spectrum in the carbonyl region.

\subsection{Sequential $\mathrm{H}^{+}-\mathrm{H}^{-}$treatment of $\mathrm{Os}_{3}(\mathrm{CO})_{9}\left(\mu_{3}-\eta^{2}-\right.$ $\left.\mathrm{C}_{2} \mathrm{Ph} \mathrm{h}_{2}\right)(\mu-\mathrm{C}(\mathrm{OMe}) \mathrm{Ph})$}

Treatment of compound 1 with $\mathrm{HBF}_{4}$ in diethyl ether solution generates an air-sensitive pale-yellow precipitate, formulated as $\left\{\left[\mathrm{Os}_{3}(\mathrm{CO})_{9}\left(\mu-\eta^{3}-\mathrm{C}_{3} \mathrm{Ph}_{3}\right)^{+}\right]-\right.$ $\left.\left[\mathrm{BF}_{4}^{-}\right]\right\}$(2). Although the crystal structure of complex 2 has not been determined, it has been carefully characterized by IR, ${ }^{1} \mathrm{H}$ and ${ }^{13} \mathrm{C}$ NMR spectroscopies. The IR spectrum in the carbonyl region reveals that the absorptions are shifted to higher energies, consistent with the complex 2 being a cationic species [13]. The ${ }^{1} \mathrm{H}$ NMR spectrum shows only the phenyl proton resonances in the range 7.63-7.24 ppm. The ${ }^{13} \mathrm{C}$ NMR spectrum of 2 by protonating $\mathrm{Os}_{3}\left({ }^{*} \mathrm{CO}\right)_{9}\left(\mu_{3}-\eta^{2}-\right.$ $\left.\mathrm{C}_{2} \mathrm{Ph}_{2}\right)\left(\mu-{ }^{*} \mathrm{C}(\mathrm{OMe}) \mathrm{Ph}\right)$ shows a broad signal at 176.6 ppm, assigned to the $C(\alpha)$ carbon in the metallacycle ring. The carbonyl carbon resonances are in a $1: 2: 1: 4: 1$ pattern ranging from 184.8 to $171.1 \mathrm{ppm}$. The $4 \mathrm{C}$ signal is revealed as arising from the Os( $\left.{ }^{*} \mathrm{CO}\right)_{4}$ unit, which equilibrates by two separate pseudo-threefold rotation [14].

Reaction of complex 2 with lithium triethylborohydride leads to the known $(\mu-\mathrm{H}) \mathrm{Os}_{3}(\mathrm{CO})_{9}\left(\mu_{3}-\eta^{3}-\mathrm{C}_{3} \mathrm{Ph}_{3}\right)$ (3) [9] and $\mathrm{Os}_{3}(\mathrm{CO})_{9}\left(\mu_{3}-\eta^{2}-\mathrm{C}_{2} \mathrm{Ph}_{2}\right)(\mu-\mathrm{CHPh})$ (4) [8] with yields of $46 \%$ and $21 \%$ respectively. Thus it appears that initial protonation occurs at the methoxy group in compound 1 to eliminate a methanol species, 
probably forming a benzylidyne intermediate $\left[\mathrm{Os}_{3}\right.$ $\left.(\mathrm{CO})_{9}\left(\mu_{3}-\eta^{2}-\mathrm{C}_{2} \mathrm{Ph}_{2}\right)(\mu-\mathrm{CPh})^{+}\right]$, which then undergoes a facile $\mathrm{C}-\mathrm{C}$ coupling reaction with the alkyne carbon and the alkylidyne carbon to yield the complex 2:

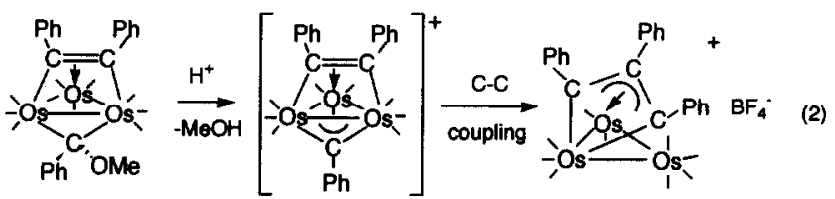

1 2

Subsequent hydride attack at the cluster framework would give compound 3 , or hydride attack occurring at $\mathrm{C}(\alpha)$ of the metallacycle ring would re-form the alkylidene complex 4:

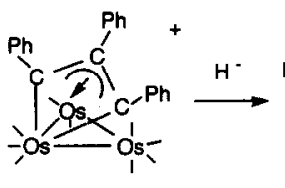

2

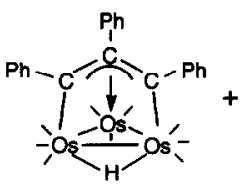

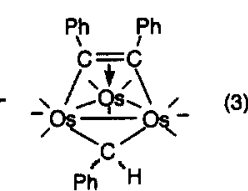

4
3.4. Thermolysis of $O s_{3}(C O)_{9}\left(\mu_{3}-\eta^{2}-C_{2} P h_{2}\right)(\mu-C$ $(\mathrm{OMe}) \mathrm{Ph})$

Heating compound 1 in refluxing hexane for $6 \mathrm{~h}$ yields a methylidene complex $\mathrm{Os}_{3}(\mathrm{COO})_{9}\left(\mu_{3}-\eta^{2}-\right.$ $\left.\mathrm{C}_{2} \mathrm{Ph}_{2}\right)\left(\mu-\mathrm{CH}_{2}\right)(5)$ as the major product (yield, $\left.43 \%\right)$ :

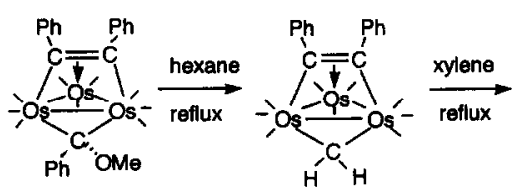

1
5

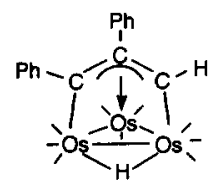

6
Compound 5 has been previously prepared by Shapley and coworkers [10] from reaction of $\mathrm{Os}_{3}(\mathrm{CO})_{9}\left(\mu_{3}-\eta^{2}\right.$. $\mathrm{C}_{2} \mathrm{Ph}_{2}$ ) with diazomethane; moreover, thermolysis of compound 5 rearranges to $(\mu-\mathrm{H}) \mathrm{Os}_{3}(\mathrm{CO})_{9}\left(\mu_{3}-\eta^{3}-\mathrm{C}_{3}\right.$ $\mathrm{HPh}_{2}$ ) (6), but under harsher conditions (in refluxing xylene) [10]. An analogous reaction with $\mathrm{Os}_{3}(\mathrm{CO})_{9}\left(\mu_{3}-\right.$ $\left.\eta^{2}-\mathrm{C}_{2} \mathrm{Me}_{2}\right)\left(\mu-\mathrm{CH}_{2}\right)$ was recently reported by Rosenberg and coworkers [15].

In order to trace the origin of the methylidene hydrogen atoms, compound 1 was heated in benzene- $d_{6}$ but forming compound 5 without the incorporation of deuterium atoms. Moreover, thermolysis of compound 1 in wet solvents containing a trace amount of $\mathrm{D}_{2} \mathrm{O}$ gave 5 , showing no deuterium labelling in the methylidene position. Thus, a pathway via eliminating a PhOMe species from compound 1 and abstracting two hydrogen atoms from solvents or moisture to give $\mathbf{5}$ is unlikely. On the contrary, heating $\mathrm{Os}_{3}\left({ }^{*} \mathrm{CO}\right)_{9}\left(\mu_{3}-\eta^{2}\right.$ $\left.\mathrm{C}_{2} \mathrm{Ph}_{2}\right)\left(\mu-{ }^{*} \mathrm{C}(\mathrm{OMe}) \mathrm{Ph}\right)\left(1^{*}\right)$ (each enriched site about

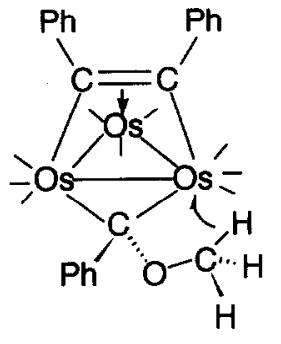

1

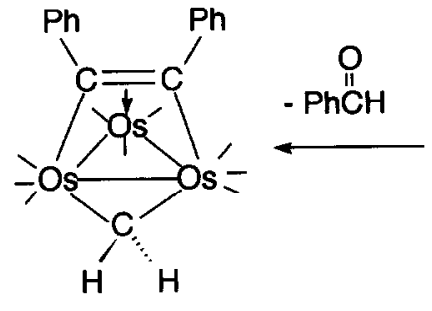

5

Scheme 1

$\left.33 \%{ }^{13} \mathrm{C}\right)$ results in $\mathrm{Os}_{3}(* \mathrm{CO})_{9}\left(\mu_{3}-\eta^{2}-\mathrm{C}_{2} \mathrm{Ph}_{2}\right)\left(\mu-\mathrm{CH}_{2}\right)$ $\left(5^{*}\right)$, with loss of ${ }^{13} \mathrm{C}$ labelling at the alkylidene carbon atom, implying a more complicated mechanism. These results may be reasonably accounted for by the reaction sequence shown in Scheme 1. Apparently, the reaction is initiated by $\mathrm{C}-\mathrm{H}$ activation of the methoxy group onto the triosmium framework, followed by hydride migration to the bridging alkylidene carbon and elimination of a benzaldehyde species to give the observed product. Supporting this mechanism, the elimination of $\mathrm{PhC}(\mathrm{O}) \mathrm{H}$ species has been confirmed by ${ }^{1} \mathrm{H}$ NMR (9.6 ppm for $-\mathrm{C}(\mathrm{O}) \mathrm{H})$ by performing the conversion of 5 to 6 in benzene- $d_{6}$ solvent in a sealed NMR tube. Note that thermally induced elimination of benzaldehyde from a triruthenium benzoyl complex was previously described by Bonnet and coworkers [16].

\section{Acknowledgment}

This research was supported by the National Science Council of Taiwan, ROC.

\section{References}

1 W.A. Herrmann, Adv. Organomet. Chem., 20 (1982) 160; (b) W.A. Ilerrmann, Pure Appl. Chem., 54 (1982) 65; (c) J. Holton, M.F. Lappert, R. Pearce and P.I.W. Yarrow, Chem. Rev., 83 (1983) 135; (d) J.P. Collman, L.S. Hegedus, J.R. Norton and R.G. Finke, Principles and Applications of Organotransition Metal 
Chemistry, University Science Books, Mill Valley, CA, 1987; (e) R.D. Adams, Chem. Rev., 89 (1989) 1703; (f) Ch. Elschenbroich and A. Salzer, Organometallics, VCH, Weinheim, 1989; (g) L.S. Hegedus, Pure Appl. Chem., 62 (1990) 691.

2 (a) K.H. Theopold and R.G. Bergman, J. Am. Chem. Soc., 103 (1981) 2489; (b) F.A. Dyke, S.A.R. Knox, P.J. Marsch and G.E. Taylor, J. Chem. Soc., Chem. Commun., (1980) 803; (c) K.H. Dötz, in H. tom Dieck and A. de Meijere (eds.), Organometallics in Organic Synthesis, Springer, Berlin, 1988, p. 85; (d) D.F. Shriver, H.D. Kaesz and R.D. Adams (eds.), The Chemistry of Metal Cluster Complexes, VCH, New York, 1990; (e) J. Robbins, G.C. Bazan, J.S. Murdzek, M.B. O'Regan and R.R. Schrock, Organometallics, 10 (1991) 2902; (f) K.H. Dötz, T. Schäfer, F. Kroll and K. Harms, Angew. Chem., Int. Edn. Engl., 31 (1992) 1236; (g) T.R. Cundary and M.S. Gordon, Organometallics, 11 (1992) 55.

3 (a) J.R. Shapley, A.C. Sievert, M.R. Churchill and H.J. Wasserman, J. Am. Chem. Soc., 103 (1981) 6975; (b) M.D. Curtis, L. Messerle, J.J. D'Errico, W.M. Butler and M.S. Hay, Organometallics, 5 (1986) 2283.

4 (a) J.C. Jeffrey, I. Moore, M. Murray and F.G.A. Stone, J. Chem. Soc., Dalton Trans., (1982) 1741; (b) F.G.A. Stone, Angew. Chem., Int. Edn. Engl., 23 (1984) 89, and references cited therein; (c) M.J. Attfield, J.A.K. Howard, A.N.M. Jelfs, C.M. Nunn and F.G.A. Stone, J. Chem. Soc., Dalton Trans., (1987) 2219.

5 (a) E.N. Jacobsen and R.G. Bergman, J. Am. Chem. Soc., 107 (1985) 2023; (b) J.R. Shapley, M.E. Cree-Uchiyama, G.M. St.-George, M.R. Churchill and C. Bueno, J. Am. Chem. Soc., 105
(1983) 140; (c) M.R. Awang, J.C. Jeffrey and F.G.A. Stone, J. Chem. Soc., Dalton Trans., (1983) 2091.

6 J.B. Keister, Polyhedron, 7 (1988) 847, and references cited therein.

7 (a) M. Tachikawa, J.R. Shapley and C.G. Pierpont, J. Am. Chem. Soc., 97 (1975) 7172; (b) C.G. Pierpont, Inorg. Chem., 16 (1977) 636.

8 A.D. Clauss, Ph.D. Thesis, University of Illinois, 1982.

9 M.R. Churchill, J.W. Ziller, J.R. Shapley and W.-Y. Yeh, J. Organomet. Chem., 353 (1988) 103.

10 A.D. Clauss, J.R. Shapley and S.R. Wilson, J. Am. Chem. Soc., 103 (1981) 7387.

11 (a) W.-Y. Yeh, J.R. Shapley, Y.-J. Li and M.R. Churchill, Organometallics, 4 (1985) 767; (b) W.-Y. Yeh, J.R. Shapley, J.W. Ziller and M.R. Churchill, Organometallics, 6 (1987) 1; (c) W.-Y. Yeh, S.R. Wilson and J.R. Shapley, J. Organomet. Chem., 371 (1989) 257.

12 B.E. Mann and B.F. Taylor, ${ }^{13}$ C NMR Data for Organometallic Compounds, Academic Press, New York, 1981.

13 W.-Y. Yeh, J.R. Shapley, J.W. Ziller and M.R. Churchill, Organometallics, 5 (1986) 1757.

14 P.D. Gavens and M.J. Mays, J. Organomet. Chem., 162 (1978) 389.

15 M. Day, W. Freeman, K.I. Hardcastle, M. Isomaki, S.E. Kabir, T. McPhillips, E. Rosenberg, L.G. Scott and E. Woff, Organometallics, 11 (1992) 3376.

16 N. Lugan, G. Lavigne, J.J. Bonnet, R. Rèau, D. Neibecker and I. Tkatchenko, J. Am. Chem. Soc., 110 (1988) 5369. 